\title{
Akibat hukum bagi kreditur setelah perjanjian perkawinan dibuat dan telah disahkan
}

\author{
William Surya Putra Handoko
}

William Surya Putra Handoko; Kantor Notaris Paulus Oliver Yoesoef, Sarjana Hukum Jalan Telomoyo Nomor 5; Malang; 65119; Jawa Timur; Indonesia.

\begin{tabular}{l} 
A R T I C L E I N F O \\
\hline Article history: \\
Received 2020-10-22 \\
Received in revised form \\
2020-11-23 \\
Accepted 2020-12-01 \\
\hline Kata kunci: \\
Perjanjian Perkawinan, Harta \\
Benda Perkawinan, Akibat Hukum \\
\hline Keywords: \\
Marriage Agreement, Matrimonial \\
Property, Legal Due. \\
\hline
\end{tabular}

DOI: https://doi.org/10.26905/

idjch. v11i3. 4408.

\section{How to cite item:}

Handoko, W. S. P. (2020).

Akibat hukum bagi kreditur setelah perjanjian perkawinan dibuat dan telah disahkan. Jurnal Cakrawala Hukum, 11(3). 351-358. doi:10.26905/ idjch.V11i3.4408.

Corresponding Author:

* William Surya Putra Handkoko

E-mailaddress: williamsph@rocketmail.com

\section{Abstrak}

Tujuan dari penulisan ini adalah untuk menganalisis permasalahan hukum akibat dari adanya perubahan status hukum kedudukan harta benda debitur dalam perkawinan yang sebelumnya merupakan harta bersama menjadi harta pribadi masing-masing suami atau isteri. Hal tersebut disebabkan karena pasca adanya Putusan Mahkamah Konstitusi, maka pasangan suami isteri dapat membuat perjanjian perkawinan selama ikatan perkawinan dan masa berlakunya sejak perkawinan tersebut dilangsungkan. Untuk menjawab permasalahan tersebut, penelitian hukum ini menggunakan pendekatan perundang-undangan dan pendekatan analisis, sedangkan teknik analisis yang digunakan adalah penafsiran gramatikal dan penafsiran sistematis. Berdasarkan hasil pembahasan, maka dapat disimpulkan bahwa dengan dibuatnya perjanjian perkawinan pasca Putusan Mahkamah Konstitusi dan perjanjian tersebut telah disahkan, maka akan berakibat hukum adanya pemisahan harta dan berlaku bagi pihak ketiga. Namun demikian, perjanjian perkawinan yang dibuat tersebut tidak boleh merugikan pihak ketiga.

Abstract
This paper aims to analyze the legal problems due to changes in the legal status of
the debtor's property in a marriage that was previously shared property into the
personal property of each husband or wife. That is because after the Constitutional
Court Ruling, a married couple can make a marriage agreement during the mar-
riage bond and the validity period since the marriage took place. To answer this
problem, this legal research uses a statutory approach and analysis approach, while
the analytical technique used is grammatical interpretation and systematic inter-
pretation. Based on the results of the discussion, it can be concluded that by making
a marriage agreement after the Constitutional Court Decision and the agreement
has been ratified, it will result in legal existence of the separation of assets and
applies to third parties. However, the marriage agreement made must not be detri-
mental to a third party.




\section{Jurnal Cakrawala Hukum, Volume 11 No. 3 Desember 2020}

ISSN PRINT 2356-4962 ISSN ONLINE 2598-6538

\section{Pendahuluan}

Pada dasarnya perkawinan adalah sebuah peristiwa atau lembaga hukum yang dilakukan oleh sepasang suami isteri yang menimbulkan akibat hukum berupa hak dan kewajiban (Satrio, 1993). Akibat hukumperkawinan terhadap pasangan suami isteri adalah timbul hak dan kewajiban selama perkawinan berlangsung serta tanggung jawab kepada anak-anak. Selanjutnya akibat hukum yang timbuladalah adanya pemisahan harta kekayaan, yang diperoleh dari sebelum perkawinan berlangsungataupun selama perkawinan berlangsungbeserta akibat hukumnya terhadap pihak ketiga.

Pasal 29 UU Perkawinan menjelaskan bahwa calon suami isteri dapat membuat perjanjian perkawinan, dengan syarat yaitu dibuat pada waktu atau sebelum perkawinan dilangsungkan, dalam bentuk perjanjian tertulis yang disahkan oleh pegawai pencatat perkawinan, isi perjanjian tidak melanggar batas-batas hukum,agama, dan kesusilaan. Perjanjian perkawinan tersebut berlaku sejak perkawinan dilangsungkan dan tidak dapat diubah kecuali ada persetujuan dari mempelai pria dan mempelai wanita selama perubahan tersebut tidak merugikan pihak ketiga.

Perjanjian perkawinan diartikan sebagai perjanjian yang dibuat oleh calon pasangan suami isteri yang isinya mengatur pemisahan harta. Perjanjian perkawinan didasari atas Pasal 1320 Kitab Undang-Undang Hukum Perdata (untuk selanjutnya disebut sebagai KUHPerdata) (Isnaeni, 2016). Pasal 1338 ayat (1) KUHPerdata tentang asas kebebasan berkontrak, jadi pasangan suami isteri dapat menentukan isi perjanjian perkawinan sesuai kehendak mereka masing-masing tanpa melanggar batas agama, kesusilaan, hukum dan kepatutan.

Pada Pasal 35, 36 dan 37 UU Perkawinan menjelaskan bahwa ada 2 macam harta benda dalam perkawinan yaitu harta bawaan suami atau isteri dan hartabersama. Akibat hukum dari per- janjian perkawinan yang dibuat oleh calon suami dan calon isteri dijelaskan pada Pasal 35 ayat (2) UU Perkawinan yaitu adanya pemisahan harta pribadi dan harta bersama, termasuk pula adanya pemisahan utang. Untuk utang yang dibuat masing-masing pribadi suami atau isteri akan menjadi tanggungan masing-masing pribadi suami atau isteri, sedangkan utang bersama akan menjadi tanggung jawab beban calon suami dan calon isteri secara bersama-sama (Istrianty, 2015). Sehingga dengan dibuatnya perjanjian perkawinan, calon suami atau calon isteri dalam melakukan perbuatan hukum terkait dengan peralihan harta bendanya tidak memerlukan lagi persetujuan dari masingmasing pasangan suami ataupun isteri.

Mahkamah Konstitusi melalui Putusan Nomor Register 69/PUU-XIII/2015 (untuk selanjutnya disebut sebagai Putusan MK) mengabulkan sebagian permohonan dari Ike Farida yang merupakan Warga Negara Indonesia (untuk selanjutnya disebut sebagai WNI) yang menikah dengan seorang Warga Negara Jepang (WNA), terhadap uji materiil atas UU Perkawinan dan Undang-Undang Nomor 5 Tahun 1960 tentang Peraturan Dasar Pokok-Pokok Agraria (untuk selanjutnya disebut sebagai UU Agraria). Pemohon didasari oleh adanya hak konstitusional WNI merasa dirugikan oleh ketentuan bahwa perjanjian perkawinan hanya dapat dibuat sebelum atau pada saat perkawinan tersebut dilangsungkan, dinilai tidak adil dan bertentangan dengan Pasal 28E ayat (2) UUD 1945.

Putusan MK mengubah beberapa ketentuan pada Pasal 29 UU Perkawinan yaitu pasangan suami isteri dapat membuat perjanjian perkawinan selama ikatan perkawinan berlangsung, padahal pada UU Perkawinan pasangan suami isteri tersebut hanya dapat membuat perjanjian perkawinan pada waktu atau sebelum perkawinan berlangsung. Kemudian perubahannya juga terdapat pada pengesahan perjanjian perkawinan tersebut, pada Putusan MK dapat dilakukan oleh notaris atau pegawai pencatat perkawinan yang berwenang 


\section{Akibat hukum bagi kreditur setelah perjanjian perkawinan dibuat dan telah disahkan}

William Surya Putra Handoko

selama perjanjian perkawinan tersebut dibuat secara tertulis, padahal pada UU Perkawinan pengesahan perjanjian perkawinan tersebut hanya dapat dilakukan oleh pegawai pencatat perkawinan (Subekti, 1985).

Selanjutnya dapat dilihat pula bahwa pada UU Perkawinan mengartikan bahwa perjanjian perkawinan tersebut berlaku sejak perkawinan dilangsungkan, namun sejak ada putusan MK, perjanjian perkawinan mulai berlaku sejak perkawinan dilangsungkan atau sejak waktu yang ditentukan lain dalam perjanjian perkawinan tersebut. Perubahan terakhir yang ada pada Putusan MK terhadap perjanjian perkawinan adalah perjanjian perkawinan dapat dicabut atau diubah dengan dasar kesepakatan pasangan suami isteri, namun demikian tidak boleh merugikan pihak ketiga, padahal pada UU Perkawinan perjanjian perkawinan tersebut dapat diubah saja, namun tidak dapat dicabut, asal dengan kesepakatan pasangan suami isteri.

Akibat hukum pasca adanya Putusan MK salah satunya yaitu dapat dibuatnya perjanjian perkawinan selama ikatan perkawinan dan masa berlakunya sejak perkawinan tersebut dilangsungkan. Hal tersebut tentunya dapat menimbulkan suatu permasalahan terhadap utang bersama yang dibuat selama perkawinan berlangsung dan apabila setelah itu suami isteri tersebut sepakat untuk membuat perjanjian perkawinan. Dengan disepakati masa berlaku perjanjian perkawinan sejak perkawinan dilangsungkan, maka terkait tanggung jawab pelunasan utang yang semula menjadi tanggung jawab bersama suami isteri akan menimbulkan masalah baru, karena sejak adanya perjanjian perkawinan tersebut maka akan terjadi pemisahan harta termasuk juga utang-utang yang akan menjadi tanggung jawab pribadi masing-masing suami atau isteri.

Kegiatan pinjam meminjam uang yang dalam hal dunia perbankan lebih dikenal dengan istilah kredit. Bank sebagai pihak kreditur memerlukan perlindungan guna menjamin pelunasan utang dari pihak debitur yaitu apabila debitur tersebut telah habis jangka waktu untuk pelunasan utang atau wanprestasi, sehingga bank memerlukan jaminan berupa agunan dari pihak debitur. Jaminan berupa agunan dapat berupa barang bergerak ataupun barang tidak bergerak, jaminan berupa agunan tersebut akan digunakan untuk melunasi utang debitur apabila telah terjadi wanprestasi dengan cara penjualan secara lelang, kemudian hasil pelelangan tersebut akan digunakan untuk membayar utangutang dari debitur, apabila terdapat sisa maka akan dikembalikan pada pihak debitur sepenuhnya.

Sebagai contoh apabila pasangan suami isteri melakukan perjanjian kredit dengan bank dengan menjaminkan aset rumah yang dibelinya dari harta bersama dalam perkawinan sebagai obyek jaminannya. Kemudian dalam perjalanannya pasangan suami isteri tersebut membuat perjanjian perkawinan yang isinya membagi atau memisahkan harta benda yang ada ke dalam penguasaan masing-masing pribadi. Apabila terjadi perubahan status kepemilikan terhadap aset rumah tersebut, maka posisi pihak bank sebagai kreditur akan menjadi rawan dirugikan karenaapabila terjadi wanprestasi maka pihak bank tidak akan serta merta dengan mudah melakukan eksekusi terhadap obyek jaminan tersebut.

Bagi pihak ketiga yang menjadi kreditur adalah penting untuk mengetahui bagaimana kedudukan harta kekayaan suami isteri terkait dengan kepastian terlunasinya piutang (Satrio, 1993). Apabila pasangan suami isteri tersebut tidak mengadakan perjanjian perkawinan, maka harta mereka merupakan harta bersama, sehingga terhadap pelunasan utang mereka adalah menjadi tanggung jawab bersama dan diambil dari harta bersama mereka. Namun apabila pasangan suami isteri tersebut mengadakan perjanjian perkawinan, maka pelunasan utang menjadi tanggung jawab masing-masing pribadi suami atau isteri (Damanhuri, 2007). Pergeseran makna perjanjian perkawinan 


\section{Jurnal Cakrawala Hukum, Volume 11 No. 3 Desember 2020}

ISSN PRINT 2356-4962 ISSN ONLINE 2598-6538

akibat adanya Putusan MK membawa pengaruh dan dampak bagi hubungan pasangan suami isteri tersebut kepada pihak ketiga apabila terdapat perjanjian yang dibuat antara pasangan suami isteri dengan pihak ketiga sebelum perjanjian perkawinan tersebut dibuat,karena Putusan MK membolehkan pasangan suami isteri membuat perjanjian perkawinan selama ikatan perkawinan berlangsung. Apabila pelaksanaan waktu berlakunya perjanjian perkawinan tersebut disepakati oleh pasangan suami isteri sejak perkawinan berlangsung sesuai dengan Putusan MK, maka akan berakibat adanya perubahan status hukum terhadap harta benda debitur atau pasangan suami isteri tersebut. Semula merupakan harta bersama, namun sejak dibuatnya perjanjian perkawinan menurut Putusan MK yang dibuat selama ikatan berlangsung dan waktu berlakunya disepakati sejak perkawinan berlangsung, maka harta mereka menjadi harta pribadi masing-masing suami atau isteri.

\section{Metode}

Jenis penelitian yang digunakan oleh peneliti adalah yuridis normatif, yaitu penelitian yang difokuskan untuk mengkaji penelitian kaidahkaidah atau norma-norma dalam hukum positif. Penelitian hukum ini menggunakan pendekatan perundang-undangan dan pendekatan analisis. Peneliti menggunakan jenis bahan hukum primer, sekunder dan tersier, sedangkan teknik analisis bahan hukum yang digunakan adalah penafsiran gramatikal dan penafsiran sistematis.

\section{Pembahasan}

\subsection{Tanggung jawab pelunasan utang se- belum dibuatnya perjanjian perkawinan}

Dapat kita lihat bahwa menurut KUHPerdata sejak dimulainya perkawinan, terjadi suatu percampuran antara kekayaan suami dan kekayaan isteri yang mencakup seluruh aktiva dan pasiva, baik yang diperoleh suami-isteri, sebelum atau selama masa perkawinan mereka berlangsung, yang juga termasuk di dalamnyaadalah modal, bunga dan bahkan utang-utang yang diakibatkan oleh suatu perbuatan yang melanggar hukum.

Apabila pasangan suami isteri tersebut dalam perkawinan tidak membuat perjanjian perkawinan, maka di antara pasangan suami isteri tersebut tidak terdapat percampuran harta benda dalam perkawinan, termasuk pula harta dan utang yang di bawa ke dalam perkawinan dan yang terjadi selama ikatan perkawinan berlangsung, jadi secara otomatis terjadi persatuan untung dan rugi. Sehingga apabila terjadi utang dengan pihak ketiga, maka harta yang dapat dijadikan pelunasan utang adalah harta benda yang merupakan harta bersama milik pasangan suami isteri tersebut. Jika harta tersebut masih tidak cukup untuk melunasi utangutangnya, maka selanjutnya yang dapat dijadikan pelunasan utang adalah harta benda milik pribadi suami atau isteri, tergantung siapa yang memiliki utang dengan pihak ketiga. Harta benda milik pribadi suami dapat dijadikan sebagai pelunasan utang terhadap utang bersama yang dibuat oleh isteri, namun harta benda milik pribadi isteri tidak dapat dijadikan sebagai pelunasan utang terhadap utang bersama yang dibuat oleh suami. Tanggung Jawab Pelunasan Utang Setelah Dibuatnya Perjanjian Perkawinan Pasca Putusan MK

Dalam penelitian ini, Penulis mengambil contoh pasangan suami isteri denganperjanjian perkawinan pisah harta seluruhnya, sehingga suami tetap memiliki harta pribadi suami dan isteri tetap memiliki harta pribadi isteri, baik terhadap harta benda perkawinan yang dibawa ke dalam perkawinan dan juga yang mereka peroleh pada saat perkawinan tersebut berlangsung, jadi sama sekali tidak ada percampuran harta di antara pasangan suami isteri tersebut. Sehingga dalam perkawinan seperti ini hanya ada 2 (dua) kelompok harta benda dalam perkawinan yaitu harta benda pribadi milik suami dan harta benda pribadi milik isteri.

Pasangan suami isteri memiliki kewajiban untuk melunasi segala utang yang dibuat selama 


\section{Akibat hukum bagi kreditur setelah perjanjian perkawinan dibuat dan telah disahkan \\ William Surya Putra Handoko}

perkawinan terhadap pihak ketiga terkait utang, seperti yang telah yang disepakati dalam perjanjian utang piutang atau perjanjian pokoknya (Judiasih, 2015). Tanggung jawab pelunasan terhadap utang bersama dapat ditentukan dari hukum yang mengatur pasangan suami isteri tersebut. Perjanjian perkawinan yang dibuat pasangan suami isteri tersebut tidak hanya mengatur pembagian tentang harta benda dalam perkawinan, namun juga mengatur pembagian tentang utang-utang dan juga beban-beban yang ada.Dalam hubungan intern antara pasangan suami isteri akan ditentukan terkait kewajiban siapa yang menanggung pelunasan utang bersama dan bagian harta siapakah yang nantinya akan dibebankan demi menjamin pelunasan utang tersebut (Saragih, 2017).Namun berbeda cerita apabila dalam perkawinan tersebut pasangan suami isteri tersebut membuat perjanjian perkawian dengan jenis persatuan hasil dan pendapatan, maka akan berakibat seluruh harta benda dalam perkawinan menjadi harta bersama, jadi terkait pelunasan utang terhadap pihak ketiga maka menjadi tanggung jawab pasangan suami isteri tersebut secara bersama-sama dan tanggung renteng.

Dalam UU Perkawinan tidak terdapat pasal yang mengatur tentang tanggung jawab terhadap pelunasan utang yang dibuat pasangan suami isteri, baik yang dibuat sebelum perkawinan maupun yang dibuat selama ikatan perkawinan berlangsung. Jadi terkait tanggung jawab terhadap pelunasan utang yang dibuat pasangan suami isteri menjadi tanggung jawab intern pasangan suami isteri serta tanggung jawab extern terhadap pihak ketiga selaku kreditur. Sehingga suami atau isteri akan menanggung sendiri terhadap utang-utang yang dibuatnya secara pribadi.

Dengan disepakati masa berlaku perjanjian perkawinan sejak perkawinan dilangsungkan, maka terkait tanggung jawab pelunasan utang yang semula menjadi tanggung jawab bersama suami isteri akan menimbulkan masalah baru, karena sejak adanya perjanjian perkawinan tersebut maka akan terjadi pemisahan harta termasuk juga utang-utang yang dibuat oleh pasangan suami isteri menjadi utang pribadi masing-masing pasangan suami isteri. Karena sejak dibuatnya perjanjian perkawinan pisah harta sama sekali antara suami dan isteri, maka akan berakibat ketiadaan kebersamaan harta di antara mereka, sehingga segala aktiva dan pasiva yang mereka peroleh sepanjang perkawinan tetap menjadi milik pribadi masingmasing suami atau isteri yang bersangkutan.

Memang sejak dibuatnya perjanjian perkawinan pasca Putusan MK dan telah disahkan, akan berakibat hukum adanya pemisahan harta dan berlaku bagi pihak ketiga, namun telah dijelaskan pada Pasal 29 ayat (4) UU Perkawinan bahwa perjanjian perkawinan yang dibuat tersebut tidak boleh merugikan pihak ketiga, jadi terkait pelunasan utang dengan pihak ketiga, maka pasangan suami isteri tersebut harus menanggung secara bersama-sama ataupun dapat diperjanjikan lain sesuai kesepakatan kedua belah pihak.

\subsection{Hak dan kewajiban yang timbul bagi kreditur dalam hal terjadi gagal bayar oleh debitur setelah perjanjian perkawin- an dibuat dan telah disahkan}

Hak dan kewajiban tersebut merupakan suatu bentuk akibat hukum dari dibuatnya suatu perjanjian dan perjanjian tersebut akan berlaku sebagai undang-undang bagi masing-masing pihak yang membuatnya sesuai dengan ketentuan Pasal 1338 KUHPerdata, sehingga perjanjian tersebut mempunyai kekuatan mengikat dan harus dijalankan oleh para pihak dengan itikad baik. Apabilaada pihak yang melanggar, makaakan ada sanksi bagi yang melanggar sesuai yang telah ditentukan dalam perjanjian tersebut.

Hak kreditur atau pihak yang berpiutang antara lain adalah mendapatkan pelunasanutang beserta bunganya sesuai yang telah tertera dan diatur dalam perjanjian utang piutang atau perjanjian 


\section{Jurnal Cakrawala Hukum, Volume 11 No. 3 Desember 2020}

ISSN PRINT 2356-4962 ISSN ONLINE 2598-6538

pokoknya, mendapatkan penguasaan terhadap barang jaminan berupa agunan tersebut, mendapatkan keleluasaan setiap waktu untukmemeriksa jaminan berupa agunan milik debitur yang dijaminkan kepada kreditur dan dapat melakukan eksekusi terhadap jaminan berupa agunan yang dijaminkan debitur apabila debitur tidak dapat melakukan pelunasan utang atau telah wanprestasi.

Kewajiban kreditur atau pihak yang berpiutang antara lain adalah memberikan dana pinjaman sesuai yang tercantum dalam perjanjian utang piutang, memelihara barang jaminan dari debitur dengan baik, bersedia memberikan berkas, surat dan akta bukti kepemilikan jaminan berupa agunanmilik debitur apabila telah terjadi pelunasan utang dan mengembalikan sisa hasil penjualan lelang apabila terdapat kelebihan hasil penjualanjaminan berupa agunan milik debitur.

\subsection{Hubungan hukum yang timbul antara kreditur dan debitur dalam hal terjadi gagal bayar oleh debitur setelah per- janjian perkawinan dibuat dan telah disahkan}

Pada dasarnya hubungan hukum yang terbentuk antara pihak kreditur dan pihak debitur adalah hubungan hukum kontraktual yang didasarkan pada suatu perjanjian utang piutang yang telah disekapati oleh para pihak, dalam hal ini perjanjian tersebut akan menimbulkan akibat hukum berupa hak dan kewajiban yang bersifat timbal balik. Perjanjian utang piutang tersebut dianggap sah apabila telah memenuhi syarat subyektif dan syarat obyektif yang terdapat pada Pasal 1320 KUHPerdata.

Dalam penelitian ini Penulis menggunakan contoh perjanjian kredit kredit kepemilikan rumah ekspress sebagai salah satu contoh perjanjian kredit bank yang berbentuk kontrak baku agar dapat mengikat dan berlaku sebagai undang-undang bagi para pihak yang membuatnya.Dalam per- janjian kredit, setiap kredit yang telah disetujui dan disepakati antara pihak kreditur dan debitur maka wajib dituangkan dalam perjanjian kredit secara tertulis. Kesepakatan dalam pelaksanaan perjanjian kredit pada umumnya sama dengan perjanjian lainnya. Para pihak dengan asas kebebasan berkontrak dapat membuat dan menyusun perjanjian dengan menentukan isinya sesuai dengan keinginan para pihak sehingga dapat menimbulkan suatu hak dan kewajiban bagi para pihak, selama bukan sesuatu yang terlarang, namun yang penting diperkenankan menurut hukum dan dimungkinkan untuk dilaksanakan. Dalam pembuatan perjanjian kredit tentunya para pihak telah menentukan isi atau klausul dalam perjanjian tersebut yang berupa hak dan kewajiban para pihak dan juga mengatur tentang wanprestasi ataupun gagal bayar yang dilakukan oleh pihak debitur.

Suatu pinjaman dari kreditur dan menjaminan pelunasan suatu utang maka dibutuhkan suatu jaminan dari debitur. Dalam perjanjian kredit, para pihak lazimnya telah menjanjikan dengan tegas bahwaapabila debitur tidak dapat membayar kredit yang terutang maka kreditur berhak mengambil sebagian atau seluruh hasil penjualan harta kekayaan yang dijaminkan tersebut sebagai pelunasan utang debitur. Dalam prakteknya yang sering digunakan adalah jaminan kebendaan berupa barang tidak bergerak. Jaminan kebendaan ada 2 macam yaitu jaminan umum dan jaminan khusus berupa benda tetap dan benda tidak bergerak. Pada penelitian ini Penulis menggunakan perjanjian kredit dengan jaminan kebendaan benda tidak bergerak berupa hak tanggungan. Pembuatan perjanjian utang piutang atau perjanjian kredit merupakan langkah awal dari proses pembebanan hak tanggungan,kemudian pembuatan Akta Pemberian Hak Tanggungan oleh Pejabat Pembuat Akta Tanah. Selanjutnya APHT tersebut akan dilakukan proses pendaftaran pada badan pertanahan nasional setempat, dan akan terbit sertifikat hak tanggungan yang memiliki irah-irah "DEMI KEADILAN 
BERDASARKAN KETUHANAN YANG MAHA ESA", sertifikat ini sebagai dasar bagi kreditur untuk dapat melakukan eksekusi terhadap obyek jaminan tersebut apabila debitur di kemudian hari tidak dapat melunasi utangnya atau wanprestasi.

Maka terhadap wanprestasi yang dilakukan oleh debitur menimbulkan suatu akibat hukum: a. Debitur diwajibkan membayar ganti kerugian yang telah diderita oleh kreditur (Pasal 1234 KUHPerdata); b. Apabila perikatan itu timbal balik. Kreditur dapat menuntut pembatalan/dapat dibatalkan perikatannya melalui hakim (Pasal 1266 KUHPerdata); c. Dalam perikatan untuk memberikan sesuatu, resiko beralih kepada debitur sejak terjadi wanprestasi (Pasal 1237 ayat (2) KUHPerdata); d. Debitur diwajibkan memenuhi perikatan jika masih dapat dilakukan, atau pembatalan disertai pembayaran ganti kerugian (Pasal 1267 KUHPerdata); e. Debitur wajib membayar biaya perkara jika diperkarakan di muka Pengadilan Negeri dan debitur dinyatakan bersalah.

Pasal 14 ayat (1) UU Hak Tanggungan menjelaskan bahwa terdapat irah-irah pada sertifikat hak tanggungan yang berbunyi "DEMI KEADILAN BERDASARKAN KETUHANAN YANG

MAHA ESA" yang mengandung arti bahwasertifikat hak tanggungan tersebut memiliki kekuatan hukum tetap dan memiliki kekuatan eksekutorial yang sama dengan putusan pengadilan. Jadi apabila debitur wanprestasi, maka kreditur selaku penerima hak tanggungan dapat langsung mengeksekusi jaminan tanpa melalui proses persidangan dan pemeriksaan melalui pengadilan serta sertifikat hak tanggungan tersebut bersifat final dan mengikat para pihak.

Pihak kreditur dalam prakteknya akan mengeksekusi terhadap jaminan berupa agunan milik debitur apabila debitur tidak dapat melunasi utangnya atau wanprestasi, kemudian hasilnya akan digunakan untuk melunasi utang debitur beserta ganti kerugian berupa biaya, kerugian dan bunga.Sejak dibuatnya perjanjian perkawinan antara suami dan isteri, maka akan berakibat ketiadaan kebersamaan harta di antara mereka, sehingga segala aktiva dan pasiva yang pasangan suami isteri tersebut dapat selama perkawinan berlangsung akan tetap menjadi milik pribadi pasangan suami isteri masing-masing. Berdasarkan Pasal 29 ayat (1) UU Perkawinan menjelaskan bahwa perjanjian perkawinan yang disahkan akan mengikat pihak ketiga, jadi perjanjian perkawinan tersebut tidak akan mengikat apabila tidak disahkan oleh pegawai pencatat perkawinan. Jadi menurut peneliti, dengan dibuatnya perjanjian perkawinan pasca Putusan MK dan telah disahkan, maka akan berakibat hukum adanya pemisahan harta dan berlaku bagi pihak ketiga, namun telah dijelaskan pada Pasal 29 ayat (4) UU Perkawinan bahwa perjanjian perkawinan yang dibuat tersebut tidak boleh merugikan pihak ketiga, jadi terkait pelunasan utang dengan pihak ketiga, maka pasangan suami isteri tersebut harus menanggung secara bersama-sama ataupun dapat diperjanjikan lain sesuai kesepakatan kedua belah pihak.

\section{Simpulan}

Berdasarkan hasil pembahasan tersebut di atas, maka dapat disimpulkan bahwa akibat hukum bagi kreditur dalam hal terjadi gagal bayar oleh debitur setelah perjanjian perkawinan dibuat dan telah disahkan adalah adanya pemisahan harta dan berlaku bagi pihak ketiga, namun demikian pada Pasal 29 ayat (4) UU Perkawinan menjelaskan bahwa perjanjian perkawinan yang dibuat tersebut tidak boleh merugikan pihak ketiga atau kreditur. Berdasarkan Pasal 29 ayat (1) UU Perkawinan agar dapat mengikat pihak ketiga atau kreditur, maka perjanjian perkawinan tersebut harus disahkan oleh pegawai pencatat perkawinan. Jadi terkait pelunasan utang dengan pihak ketiga atau kreditur, maka pasangan suami isteri tersebut harus menanggung secara bersama-sama ataupun dapat diperjanjikan lain sesuai kesepakatan kedua belah pihak. 


\section{Jurnal Cakrawala Hukum, Volume 11 No. 3 Desember 2020}

ISSN PRINT 2356-4962 ISSN ONLINE 2598-6538

\section{Daftar pustaka}

Damanhuri HR, H.A. 2007. Segi-segi Hukum Perjanjian Perkawinan Harta Bersama. Mandar Maju. Bandung.

Hartanto, Andy. 2012. Hukum Harta Kekayaan Perkawinan (Menurut Burgerlijk Wetboek dan Undang-Undang Perkawinan). Lakatitbang. Yogyakarta.

Isnaeni, Moch. 2016. Hukum Perkawinan Indonesia. PT Refika Petra Media. Surabaya.

Istrianty, Annisa. (2015). Akibat Hukum Perjanjian Perkawinan Yang dibuat Setelah Perkawinan Berlangsung. Privat Law. Volume 3. Fakultas Hukum Universitas Sebelas Maret. Surakarta.

Judiasih, Sonny Dewi. 2015.Kajian Terhadap Kesetaraan Hak dan Kedudukan Suami dan Isteri atas Kepemilikan Harta Dalam Perkawinan. Refika Aditama. Bandung.

Kitab Undang-Undang Hukum Perdata.

Pramasantya, O.S., 2017. Perjanjian Perkawinan Pasca Putusan Mahkamah Konstitusi Nomor 69/PUUXIII/2015. Jurnal Cakrawala Hukum, 8(2), pp.191200.

Pratiwi, P.F.P., Suprayitno, S. and Triyani, T., 2019. Upaya Hukum Untuk Menjerat Tindakan Pelakor Dalam Perspektif Hukum Adat Dayak Ngaju. Jurnal Cakrawala Hukum, 10(2), pp.209-217.
Peraturan Pemerintah Republik Indonesia Nomor 9 Tahun 1975 tentang Pelaksanaan Undang-Undang Nomor 1 Tahun 1974 tentang Perkawinan.

Putusan Mahkamah Konstitusi Nomor 69/PUU-XIII/ 2015.

Saragih, Julius Martin. (2017). Pertanggungjawaban Hutang-Hutang Persatuan Setelah Putusnya Perkawinan. Diponegoro Law Journal. Volume 6. Nomor 1. Fakultas Hukum Universitas Diponegoro. Semarang.

Satrio, J. 1993. Hukum Harta Perkawinan. Citra Aditya Bhakti. Bandung.

Subekti, R. 1985. Hukum Pembuktian, Cet. 7. Pradnya Pramita. Jakarta.

Undang-Undang Nomor 5 Tahun 1960 tentang Peraturan Dasar Pokok-Pokok Agraria.

Undang-Undang Nomor 4 Tahun 1996 tentang Hak Tanggungan Atas Tanah Beserta Benda-Benda Yang Berkaitan dengan Tanah.

Undang-Undang Republik Indonesia Nomor 1 Tahun 1974 tentang Perkawinan.

Undang-Undang Nomor 37 Tahun 2004 tentang Kepailitan dan Penundaan Kewajiban Pembayaran Utang. 